\title{
A Study on the Impact of ICT on Collaborative Learning Processes in Libyan Higher Education
}

\author{
Thuraya Kenan, Abdussalam Elzawi, Crinela Pislaru, Maysoun Restoum \\ School of Computing \& Engineering \\ University of Huddersfield \\ Huddersfield UK
}

\begin{abstract}
This paper presents the conclusions of a study on the impact of ICT on collaborative learning processes in Libyan Higher Education (LHE). The quantitative analysis of the answers to a questionnaire (completed by Libyan full-time lecturers at the universities of Tripoli, Garyounis, Gharian and Ezawia) shows the necessity to design and develop more classroom activities and interactive online applications, enabling the development of team-building skills required by employers.

The influence of limited Internet bandwidths in Libya on collaborative learning processes in $\mathrm{HE}$ is then presented. It is obvious that HE institutions need to develop proactive strategies that envisage and anticipate learners' future learning needs and requirements in this transition period of moving towards an increasingly digitalized, networked and knowledge-based society.

The paper also contains the analysis of a SWOT model considering the factors that must be considered in relation to collaborative learning within the university teaching process, such as intelligent multimedia, Internet technologies, and knowledge management. The employment of modern technology will enable the development of innovative and inspiring collaborative learning environments where lecturers are expert designers of intellectual experiences for students, who become active participants to the learning processes.
\end{abstract}

\section{Introducation}

Information and communication technology (ICT) is now considered an integral part of people's whole lifestyle. It has been adopted in the field of Higher Education Institutes (HEIs). Initially, a number of key challenges have faced educational organisers; decision makers and management teams as a result of adopting ICT and computer networks in the educational environment. These challenges are related to the ability to identify a suitable long-term strategic visualisation. The identification of a strategic visualisation can be effectively delivered by embracing better strategic management techniques, which can assist the HEIs in balancing the stresses of change, continuousness, stability and resources. Libyan higher education institutions (LHEIs) need to make more efforts to increase the use of ICT in teaching and learning processes.

With an increase in the number of students enrolling in colleges, compared with a decline in the number of qualified teachers, and their ICT experiences and the increasing demand for accountability, and anxieties about the social and economic position of higher education, LHEIs have forced employment for "successful, selfsustaining client oriented providers of education in a rapidly changing borderless education world" [1]. The rapid progression of ICT has also reacted to different approaches to knowledge creation, management, and delivery methods. LHEIs have remained behind other areas in embracing improvement and ICT. On the other hand, they do not have clear ideas about ICT's role in improving the learning process to involve all stakeholders and organizational structures [2].

Limited connections have been found between the provision of ICT and the higher education improvement process in Libya. ICT tools were separate from the improvement process, except for departments such as electrical engineering and computer science that facilitate additional technological tools. Interestingly, in the mid 1990s, LHEIs started implementing the improvement process; this proceeded without changes in academic work practices. Recently, it has become apparent that higher education improvement cannot take place without paying attention to ICT, specifically those applications that affect education management and administration, and support of teaching and learning [3].

The future of LHEIs and universities in Libya should not only be imagined or perceived; it should be executed and implemented. Therefore, there is a need to adopt a suitable strategic architecture or a planning design to perceive the future of these HEIs, as well as to increase competitive advantage in the changed educational situation. This trend is dependent on the presence of larger 
leadership, complex communications, and teamwork. Thus, those HEIs which acquire and use new technical knowledge can increase and improve competitiveness and formulate an effective strategy.

Critically, the LHEIs seek to follow the international standard and compete with other countries' HEIs. This goal is an important mission by the LHEIs in moving toward a knowledge society in which ICT is considered a prerequisite.

\section{E-learning implementation in LHEIs}

LHEIs are still facing a critical absence of skilled specialists who recognize basic and progressive programming for planning, designing, and implementing branched information systems and managing huge scale e-learning projects. The high turnover rate of skilled technical staff is another problem in the LHEIs, which have seen continuous deterioration in their ability to recompense salaries, which were previously competitive with the private companies [4].

The LHEIs have found it difficult to motivate the technicians to assist them in expanding and building wide networks, and developing and managing administrative systems, research, the curriculums of the courses and the applications. A number of LHEIs have worked hard to solve this problem by launching wide-ranging and continuing professional development programmes for their staff and utilizing their computer science and electrical, network, and computer engineering departments.

There are also a number of challenges affecting Libyan students in the learning process, which can be improved through using ICT and intelligent multimedia, which includes text, sound, animations and colourful, moving images. This can increase the educational benefits for students, as well as developing their skills [2]. The teaching load in Libyan universities is notably heavy; on average, the number of teaching hours for academic staff is 24 hours/week and sometimes more. Libyan universities have not yet established a scientific research tradition [4]; [5]. Hence, even Professors deem that it is difficult to find time for research activity and educational development [6]. Interestingly, a number of academic staff do undertake extra activities such as writing and publishing, e.g. textbooks, to increase their income [3]; [7]; [8] and [9].

LHEIs have taken collaborative learning into consideration as a valid mode for educational processes. As a result, the Libyan Business Executive Survey/ Global Competitiveness Report (LBES/GCR) has ranked Libya to be 97 th out of 111 countries in university/industry research collaboration. The majority of the LHEIs have not appointed a staff member with formal qualifications in either distance learning or Elearning [10]. In fact, the Ministry of Libyan Higher Education, which is the legislative body responsible for endorsing degrees from foreign universities, does not endorse a degree obtained through either distance learning or E-learning. Without the approval of the Ministry, students cannot gain any advantage in the workplace from their degrees [11]. This is of great significance and could be developed.

\section{Investigation of the technological contexts for e-learning implementation}

Teaching and learning are the cornerstones of most LHEIs. However, maintaining the quality of such processes is a continuous challenge [9]. The main teaching methods used by LHEIs are traditional for three main reasons:

- The annual increase in the number of students enrolled.

- Restrictions on financial resources and staff training.

- The administration system.

In spite of the known weaknesses of such an approach, traditional teaching has provided teachers with the means to deliver the required course materials to an ever-increasing number of students and provide those students with a clear-cut minimum of materials such that they can easily memorise them [12]. Therefore, generally HE students do not contribute to the learning process in the classrooms. They are only listening and taking notes. Furthermore, the use of new technology in LHEIs (such as computers and multimedia in general) is way behind international best practice. But to involve students effectively in the learning processes, the HEI should adopt an "active learning" approach - whereby the students use resources outside classrooms, in libraries, the Internet, interviews or focus groups, to obtain information [13].

There are relationships between students, academics, administrators and technical staff, which are confirmed through observations, experiences, many survey results and other studies. These have represented many attempts to analyse IT implementation by using the SWOT model in different LHEIs since 2003 [14]. Kenan in [3] has presented the Strengths, Weaknesses, Opportunities and Threats (SWOT) as a model for a new IT strategy; other 
factors that must also be considered in relation to collaborative learning within the university teaching process. The SWOT analysis model shows that the strategy is useful for determining methods to achieve successful implementation of IT in the LHEIs by including intelligent multimedia and internet technologies [4]. This strategy aims to help decision-makers at departmental level to decide on opportunities with respect to the experience as well as the perceptions of instructors, students, administrators and technical staff about using web-based instruction with the institution [3].

Collaborative learning and IT strategy can offer a framework for assessing the impact of all implementation stages. The strategy should be appropriately flexible to accommodate changes and developments in online learning products, services and technology. The implementation stages in an official setting also need to include strategic planning [15].

\subsection{The methodology}

This research was conducted using a quantitative approach in order to collect statistical data for a large group of participants that reflects their perspectives [16]. A questionnaire was used to collect the quantitative data. It is considered to be the most common instrument used in academic research [17].

The questionnaire was designed using an online package (Smart survey) to avoid missing answers. This confirms that the Internet technologies work is parallel with all education applications. Thus, the classroom activities and interactive online applications enable the development of the team-building skills required by employers.

\subsection{Sample and questionnaire}

This article aims to present the results of a questionnaire distributed to a sample of 41 Libyan lecturers (17 Libyan lecturers work as full-time in different LHEIs, plus 24 Libyan lecturers study in the UK to get their higher degree) who were also full-time lecturers at the universities of Tripoli, Garyounis, Gharian and Ezawia.

\subsection{The results}

3.3.1. Participants' Profile. these were taken into consideration as important aspects of data collection that identify the characteristics of participants. Table 2 outlines the profiles of the participants under investigation

Table 2. Participants' profiles

\begin{tabular}{|c|c|c|c|}
\hline $\begin{array}{c}\text { Statistic } \\
\text { Data }\end{array}$ & Categories & UK (\%) & Libya (\%) \\
\hline \multirow[t]{5}{*}{ Age } & - 30 year & $8.33 \%$ & $5.88 \%$ \\
\hline & $31-35$ & $16.67 \%$ & $0.00 \%$ \\
\hline & $36-45$ & $29.17 \%$ & $64.71 \%$ \\
\hline & $46-55$ & $41.67 \%$ & $23.53 \%$ \\
\hline & +55 year & $4.17 \%$ & $5.88 \%$ \\
\hline \multirow[t]{2}{*}{ Gender } & Male & $37.50 \%$ & $52.94 \%$ \\
\hline & Female & $62.50 \%$ & $47.06 \%$ \\
\hline \multirow[t]{6}{*}{ Qualification } & Higher National & $0.00 \%$ & $5.88 \%$ \\
\hline & Baccalaureate & $10.53 \%$ & $5.88 \%$ \\
\hline & Diploma & $0.00 \%$ & $5.88 \%$ \\
\hline & Master & $42.11 \%$ & $64.71 \%$ \\
\hline & M.Phil. & $21.05 \%$ & $5.88 \%$ \\
\hline & $\mathrm{PhD}$ & $26.32 \%$ & $11.76 \%$ \\
\hline Teaching & -2 years & $20.83 \%$ & $17.65 \%$ \\
\hline \multirow[t]{6}{*}{ experience } & $2-5$ & $45.83 \%$ & $17.65 \%$ \\
\hline & $6-8$ & $4.17 \%$ & $35.29 \%$ \\
\hline & $9-11$ & $4.17 \%$ & $11.76 \%$ \\
\hline & $12-15$ & $4.17 \%$ & $5.88 \%$ \\
\hline & $16-20$ & $8.33 \%$ & $11.76 \%$ \\
\hline & +20 years & $12.50 \%$ & $0.00 \%$ \\
\hline \multirow[t]{9}{*}{ Faculties } & Science & $12.50 \%$ & $47.06 \%$ \\
\hline & Medicine & $8.33 \%$ & $5.88 \%$ \\
\hline & Arts & $0.00 \%$ & $0.00 \%$ \\
\hline & Engineering & $25.00 \%$ & $76.47 \%$ \\
\hline & Education & $20.83 \%$ & $11.76 \%$ \\
\hline & Languages & $12.50 \%$ & $5.88 \%$ \\
\hline & Business & $29.17 \%$ & $11.76 \%$ \\
\hline & Info. Tech. & $25.00 \%$ & $17.65 \%$ \\
\hline & Other & $8.33 \%$ & $5.88 \%$ \\
\hline
\end{tabular}

Table 2 summarises participants' profiles, comparing between Libyan lecturers who studied in the UK, and others who worked full-time in Libyan universities. The majority of the participants who studied in the UK (more than $40 \%$ ) belonged to a group aged (46-55), while the majority of those who worked in Libya (approximately $65 \%$ ) belonged to a group aged (36-45). Furthermore, the majority of the participants based in the UK were female (more than 60\%), whereas there was no significant difference in gender between the participants involved in Libyan universities. Furthermore, approximately (47\%) of the participants in the UK had M.Phil and PhDs, while 
less than (20\%) had the same qualification in Libya. In addition, more than $(45 \%)$ of the participants based in the UK had (2-5) years of experience, while approximately (35\%) of the participants in Libya had 6-11 years' experience. Finally, for the faculties, the majority of the participants in the UK studied in the Business faculty, while the majority of those in Libya worked in the Engineering faculty.

3.3.2. Teaching time. The participants were asked to determine how many hours they spent weekly in terms of teaching. See Figure 1.

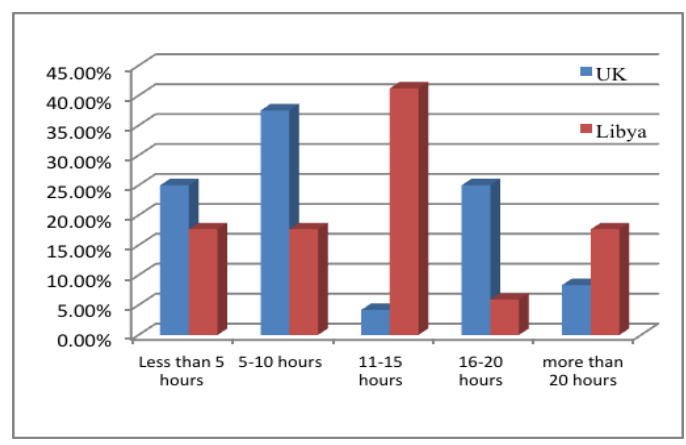

Figure 1. Hours of teaching time per week

Figure 1 shows that Libyan tutors who worked in Libya spent more time teaching than the Libyan tutors in the UK; approximately $40 \%$ of the participants working in Libya spent between (11-15) hours per week in teaching, while the percentage was less than $5 \%$ of the participants studied in the UK. In contrast, more than $(20 \%)$ of the participants studied in the UK spent between (16-20) hours, while it was approximately (6\%) for those who worked in Libya. That reflects that the lecturers spent a long time teaching. The overloading of teaching might affect the quality of teaching or might affect time available for research or developing skills. This result confirms the findings of [4] and [6], which addressed how teaching overloading and long teaching hours in Libyan universities influences tutors in terms of decreasing research activities and educational development.

3.3.3. Time spent on the Internet. The participants were asked to determine the amount of time spent using the Internet in general per day. See Figure 2.

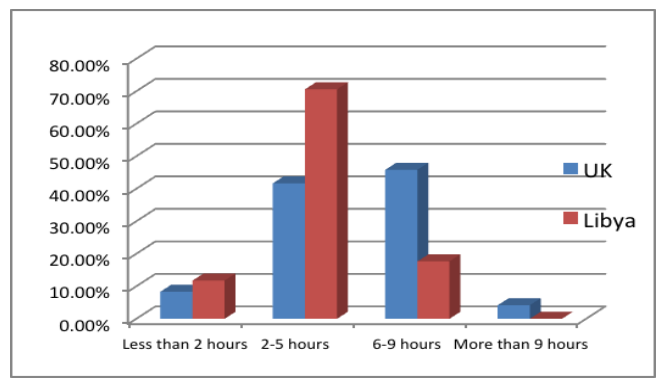

Figure 2. Time spent using Internet per day

According to Figure 2, the time spent by the participants who worked in the UK was more than the time spent by those participants who worked in Libyan universities. The majority of the participants spent (2-5) hours daily using the Internet. More than $70 \%$ of the participants working in Libya spent (2-5) hours per day using the Internet, while more than $45 \%$ of the participants based in the UK spent (6-9) hours per day. These results assert the findings of [1], [11], and [13]. The style of education system in Libya, based on traditional ways of teaching, might affect the participants' usage of the Internet. That reveals that the quality and the accessibility of Internet technology in the UK might be better that the Internet in Libya, or that there might be a lack of skills.

3.3.4. The value of using Internet technologies and intelligent multimedia. The participants were asked if they believed that using Internet technologies and intelligent multimedia could add value to their lectures. See Figure 3.

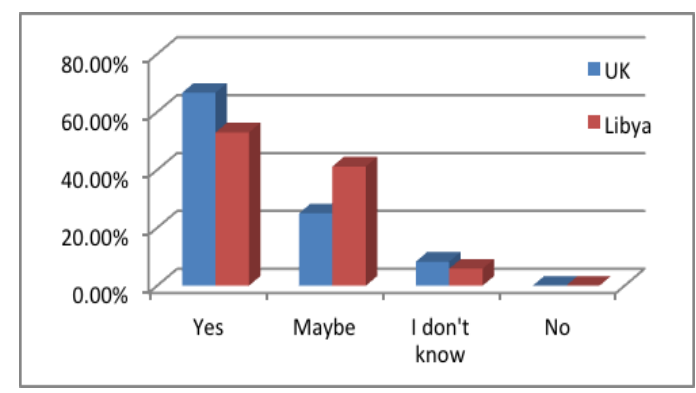

\section{Figure 3. Rating the value of using Internet technologies}

As seen in Figure 3, the participants working in the UK were aware of the value of the internet and intelligent multimedia more than those who worked in Libyan universities; however, more than $50 \%$ of the participants 
in the UK and Libya found that it was useful to adopt IT to enhance their lectures and support the curricula; nobody indicated that it was not useful. That might demonstrate their awareness in the educational process. This demonstrates that the lecturers were interested in using IT applications to support their lectures, which agreed with [Libyan Business Executive Survey] and [3], which showed that LHEIs were aware of the importance of adopting ICT in the academic field. That awareness might be reflected in the participants' perspectives.

3.3.5. Time spent using technology in teaching. The participants were asked to determine the amount of time spent weekly using technology for teaching. See Figure 4.

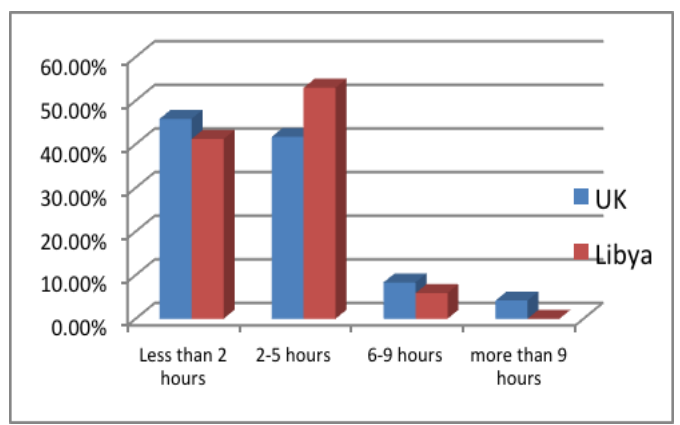

Figure 4. Time spent using technology in teaching per week

According to Figure 4, of the majority of the participants worked in Libya, approximately $52 \%$ spent (2-5) hours per week, while approximately $5 \%$ of them spent (6-9) hours weekly. In contrast, more than $40 \%$ of the participants based in the UK spent (2-5) hours weekly using the technology in teaching, whilst approximately $9 \%$ used it for (6-9) hours per week. Thus, it appeared that the time spent using technology for teaching per week was inadequate, comparing this result with the time spent in teaching per week. This result confirms the need to implement an active learning approach [13].

3.3.6. Benefits of e-learning implementation. It was crucial to identify the benefits that would be obtained from implementing e-learning in LHE. See Figure 5.

As seen in Figure 5, the majority of participants agreed or strongly agreed that implementing e-learning in LHEIs would increase achievement and provide a set of benefits. On the other hand, more than $5 \%$ of the participants strongly disagreed that implementing elearning in LHEIs would assist in solving some educational problems, while approximately $4 \%$ of the participants based in the UK strongly disagreed that elearning would help in developing the curriculum, motivating students, obtaining skills, managing time and learning other languages. This reveals that the participants might be aware of the importance of adopting e-learning systems. This result confirms the results of [3], [9]. Thus, implementing e-learning in LHEIs is useful in terms of enhancing the teaching and learning process.

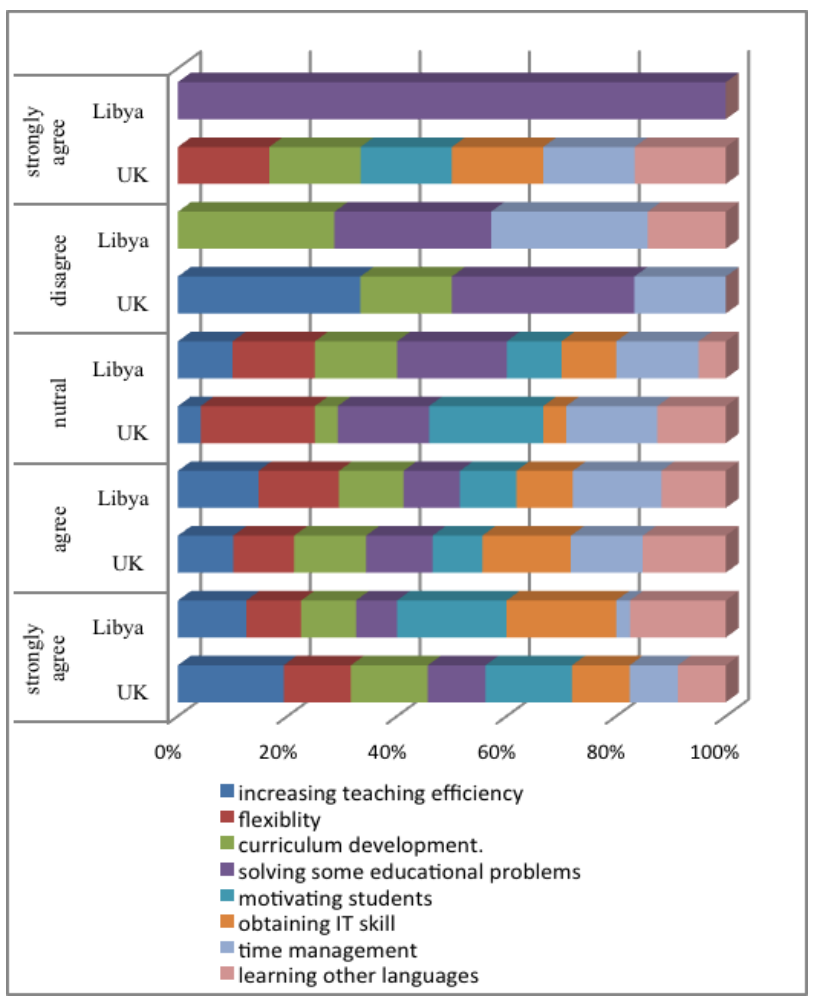

Figure 5. Benefits of e-learning implementation

3.3.7. Important elements of e-learning implementation. The participants were asked to select important elements that affect the successful implementation of e-learning. See Figure 6.

Figure 6 shows that the most important element of elearning implementation was the development of ICT; this was agreed by more than $95 \%$ of the participants working in Libya, and more than $75 \%$ of those who studied in the UK. 


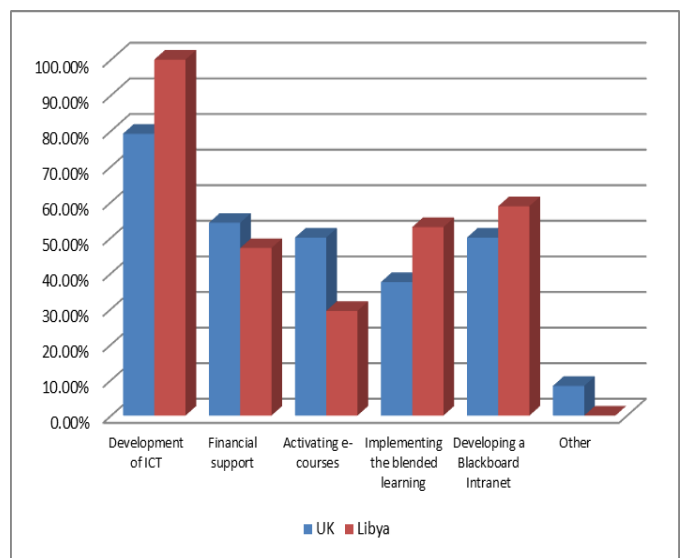

Figure 6. Important elements for successful e-learning implementation

In contrast, activating e-courses was the least important element, with less than $50 \%$ of both participants acknowledging it; this disagrees with the results of [3], where implementing e-learning required the development of ICT tools for better achievement.

3.3.8. Barriers to e-learning implementation. However, the participants were aware of the importance of applying e-learning in LHEIs; the participants faced a number of barriers. See Figure 7.

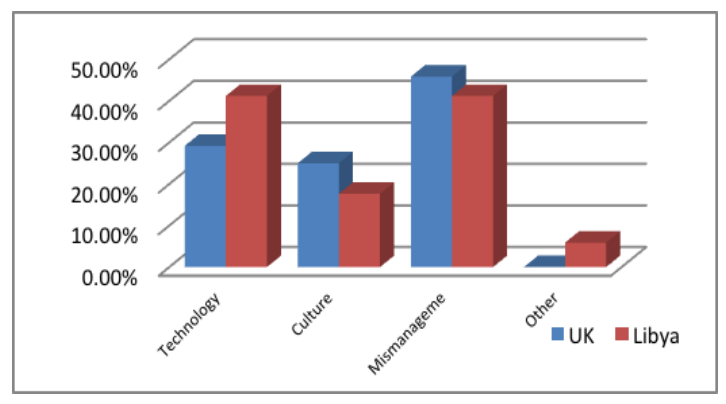

Figure 7. Barriers to e-learning implementation

According to Figure 7, mismanagement barriers were the most significant barriers confronting both sets of participants, with a response of approximately $40 \%$ by both of them. These barriers might be related to a lack of legislation, a lack of education strategy, and policy rules. On the other hand, cultural issues were less important barriers for the participants who worked in Libya (approximately 15\%), while they accounted for more than $20 \%$ for those based in the UK. Cultural barriers may refer to the rejection of a change in the education system, or it might be as a result of a lack of skills. Furthermore, approximately $5 \%$ of the participants working in Libya indicated other barriers that were about security, cost and free time. There are numerical references to confirm this, which are [2], [14] and [15]. Adopting a SWOT analysis approach is useful in terms of identifying the main barriers that faced the participants in terms of implementing e-learning.

\subsubsection{Satisfaction with the Internet speed on-campus.}

Participants were asked to evaluate their satisfaction level with the Internet speed operating on-campus. See Figure 8 .

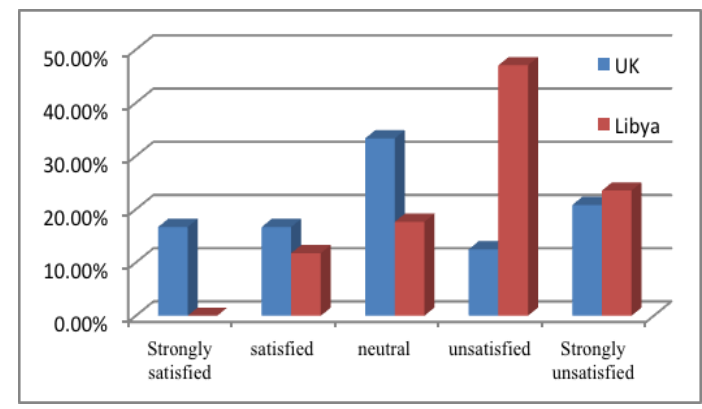

Figure 8. Participants' satisfaction with the Internet speed on campus

According to Figure 8, the majority of the participants working in Libya (approximately 45\%) were dissatisfied with the Internet speed provided on campus, while approximately $10 \%$ of them were satisfied. In contrast, approximately $20 \%$ of the participants in the UK were strongly dissatisfied, whilst more than $30 \%$ of them were neutral. The dissatisfaction of the participants working in Libya might because of a lack of Internet network, disconnection or slow network. Critically, it was unexpected that the majority of the participants studied in the UK would be neutral. That might reveal that they do not consider the importance of Internet quality in enhancing the educational process. The authority of the Ministry of the LHE can affect participants' dissatisfaction. Furthermore, all barriers and difficulties facing the participants can be reflected in their satisfaction level, either negatively or positively.

3.3.10. Cost of Off-campus Internet Access. Finally, the participants were asked to identify whether Internet cost outside of the campus was expensive. See Figure 9. 


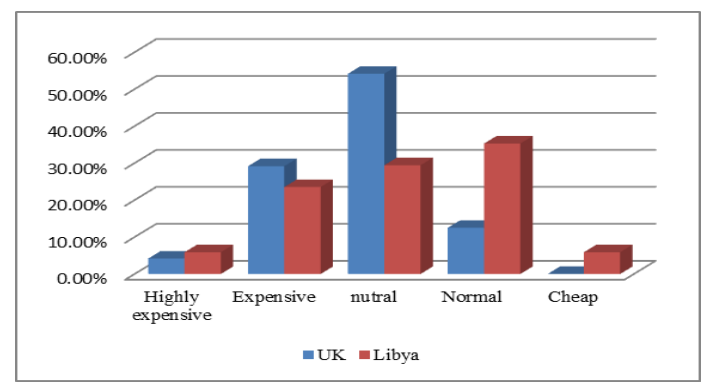

Figure 9. Cost of off-campus Internet access

In Figure 9, the majority of the UK participants (approximately 50\%) were neutral, in comparison with more than $25 \%$ of those who worked in Libya. That might be because they used the Internet from their offices. On the other hand, more than $30 \%$ of the participants working in Libya indicated that the cost of the Internet off-campus was normal, while approximately $20 \%$ of them mentioned that the cost was expensive. Hence, implementing e-learning and collaborative learning can decrease the cost of access[14].

\section{Libyan Internet bandwidth constraints}

Bandwidth in Libya suffers from a lack of ICT resources, mainly in the HEIs. This is as a result of participating in the educational institutions and increasing license costs for authorisation to connect [5]. Most countries in Africa do not have satisfactory international bandwidth. According to Jensen in 2012, almost $60 \%$ of African countries have satisfactory bandwidth [5]; however, this percentage is less than the normal average of HEIs in developed countries. Only six African countries have a reasonable bandwidth [18]; Libya still needs huge efforts to jump actively into a significant stage of improving the performance of HEIs. Table 3 shows the distribution of outgoing bandwidth in Africa.

Table 3. The bandwidth in Africa [18]

\begin{tabular}{c|c|c}
\hline African Outgoing Bandwidth & $\begin{array}{c}\text { Countries } \\
\text { Bandwidth } \\
\text { (Mbits/sec) }\end{array}$ & \% \\
\hline Egypt, South Africa, Morocco & $100-500$ & 6 \\
\hline Algeria, Senegal, Tunisia & $50-100$ & 6 \\
\hline $\begin{array}{c}\text { Botswana, Gabon, Kenya, Nigeria, Sudan, } \\
\text { Tanzania, Zimbabwe }\end{array}$ & $10-50$ & 13 \\
\hline $\begin{array}{c}\text { Angola, Cameroon, Côte d'Ivoire, Libya, } \\
\text { Mali, Namibia, Uganda, Zambia }\end{array}$ & $5-10$ & 15 \\
\hline $\begin{array}{c}\text { Benin, Burkina Faso, Burundi, Cape } \\
\text { Verde, Central African Republic, Chad, } \\
\text { Comoros, Congo, DR Congo, Djibouti, }\end{array}$ & Less than 5 & 60 \\
\hline
\end{tabular}

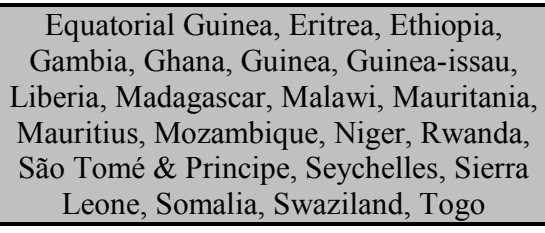

LHEIs try to override additional challenges that should be concurrently addressed in order to find a suitable improvements policy aiming to address access and high costs of bandwidth:

1. Cost of Megabits of connections is expensive. This affects the availability for the majority of LHEIs.

2. Most LHEIs do not have policies regarding ways in which to optimize their existing bandwidth and manage the circulation and usage.

3. The current infrastructure such as electricity, local intranet and the technical team's skills, is still underlying. It is insufficient to provide high bandwidth exhaustive applications.

4. There is a lack of suitable strategic will and district cooperation between the LHEIs to profit from an economy of balanced or accumulated bandwidth.

5. Incomplete knowledge and limited information about appropriate technologies (optical fibre, satellite types, other bandwidth tools) fit for distinctive settings in the LHEIs.

It is obvious that the limited Internet bandwidth in Libya negatively affects the effectiveness of collaborative learning processes. It is, therefore, necessary to develop ICT strategies which will contain solutions aiming to improve current learning performance in the LHEIs.

\section{The modern SWOT analysis for the ICT in the learning and teaching in LHEIs.}

The SWOT analysis is an essential step to analyse various factors before implementing any solution to improve ICT in teaching or develop collaborative learning at any institution. The success or failure of any collaborative learning system initiative will be directly related to the quality of strategic thinking that underpins it. It is thus important to have a collaborative learning strategy in place before the starting in stage from the implementation process. See Table 4.

The collaborative learning initiative must be tied to the institution's core business to ensure that the quality of the educational processes is enhanced [3]. SWOT analysis should help the decision makers at departmental level to decide on opportunities with respect to choosing the appropriate policy issues for it, and the following factors should be considered: improvement of learners' 
knowledge, learning outcomes, efficiency of the teaching and learning processes, and the reductions of costs.

Table 4. SWOT analysis for the ICT in LHEIs

\begin{tabular}{|c|c|}
\hline Strength points & Weakness points \\
\hline $\begin{array}{l}\text { - Annual increase in student } \\
\text { numbers } \\
\text { - The proliferation of digital } \\
\text { technology, because the majority of } \\
\text { people are using computers and } \\
\text { social media channels. } \\
\text { - The need to eliminate the } \\
\text { administrative corruption aspects. } \\
\text { - Libya has a strategic } \\
\text { geographical location in Africa. } \\
\text { They could use the collaborative } \\
\text { learning packages developed by } \\
\text { companies situated in the south of } \\
\text { Libya. }\end{array}$ & $\begin{array}{l}\text { - Lack of training } \\
\text { courses for students, } \\
\text { technical and academic } \\
\text { staff. } \\
\text { - Lack of technological } \\
\text { support and maintenance } \\
\text { for the Lab tools and } \\
\text { computers. } \\
\text { - Lack of online library } \\
\text { catalogues in LHEIs. } \\
\text { - Mismanagement. } \\
\text { - Post-war chaos that } \\
\text { pervades all sectors of } \\
\text { Libyan society. }\end{array}$ \\
\hline Opportunity points & Threat points \\
\hline $\begin{array}{l}\text { - The government policy system } \\
\text { that looks to support the LHEIs has } \\
\text { been changed since } 2011 \text {. } \\
\text { - Official recognition of education } \\
\text { certificates of distance or } \\
\text { collaborative learning. } \\
\text { - Create new business strategies to } \\
\text { attract students from other African } \\
\text { countries. } \\
\text { - Reduce the migration of skilled } \\
\text { and intelligent people from Libya. } \\
\text { - Create a competitive educational } \\
\text { environment with neighbouring } \\
\text { countries. }\end{array}$ & $\begin{array}{l}\text { - Numerous barriers } \\
\text { related to collaborative } \\
\text { learning processes } \\
\text { stages. } \\
\text { - Preference for using } \\
\text { only traditional } \\
\text { academic methods in } \\
\text { education. } \\
\text { - Lack of support from } \\
\text { the government. } \\
\text { - Increased migration of } \\
\text { skilled and intelligent } \\
\text { people from Libya. }\end{array}$ \\
\hline
\end{tabular}

\section{Collaborative learning and the quality of Internet technology}

Collaborative learning has an essential impact on the development of higher education. It has been practiced in various sectors, whether public or private, and in education and business [15]. However, collaborative learning could be a constituent part of traditional learning, alongside e-learning. It encourages students to achieve their qualifications in higher education, especially those who are located far away. It can also be low-cost and timesaving for both lecturers and students [14].

There is a requirement to redesign the current curriculum in LHEIs in order to find a more comprehensive method, and to adopt intelligent multimedia in the current system. In the educational process, there is a need to place emphasis on the basic concepts of acquiring information, providing feedback sessions on the information, and consider different information processing methods and characteristics [19]. Firstly, there is a need for students to acquire basic skills for finding information, categorising it and broadcasting or publishing it [14]. Internet technology is used for improving these skills and obtaining the right perception of the information revolution. The massive recruitments of students in terms of gaining such technological understanding can serve Libyan development plans through their future participation in manufacturing, marketing and global competition [3]. Secondly, there is another need for the educational curricula in the Arabic world to apply and include Internet technologies.

The means offered by intelligent multimedia, such as the Internet, e-mail, e-motivations, educational videos, and other applications should be used as methods of teaching and learning. Thirdly, it is necessary to work on creating a digital environment such as an Arabic information network, in collaboration with all Arab countries. It should contribute to a higher extent to feed Arabic educational political and economic systems with all necessary data and information. Improving the performance of the HEIs in Arabic countries can therefore be done by adopting collaborative learning, including the courses of training, which should be offered for Libyan lecturers to assist them in finding appropriate methods of electronic data processing, and to achieve the purposes of courses they teach.

Furthermore, the students enrolled in different courses should be trained in the practice of Internet technologies to improve their skills, thereby, attaining better results [11].

The lecturers play a fundamental role. They can use and develop different Internet applications and tools such as intelligent multimedia and collaborative learning, which assist them in delivering information to students. Offering appropriate training for the lecturers is necessary to enhance their knowledge and skills, which are relevant to their work performance. However, they are not the only group to successfully adopt and implement it. The students can also reflect a positive learning environment. The training is the main concern of the LHEIs in implementing any form of collaborative learning methods. "Lecturers with inadequate training of e-learning in the real educational environment can pose a problem in balancing the learning process with students" [3]. 


\section{Conclusion}

This paper has displayed the current state of ICT and collaborative learning systems that show that, despite some progress, LHEIs are at a crossroads in formulating ICTs beneficial to their academic projects; it also considers implications for learning and teaching and their development. Regardless of the huge potential profits, it is still unclear as to what influences ICTs may have on teaching and learning.

In considering Libya's agenda in research on the ICT and the higher education system, it is critical to consider the difficult negotiations between different actors such as local different areas, different education levels and the implications of ICT applications to social and organisational development in the LHE system. More coordination and resource sharing between LHEIs could be beneficial as universities move to combine ICT fully into their teaching and learning. The creation of regional policies for sharing information on ICT strategies and courseware and exchanging experiences are critical to increasing the positive contribution of ICTs to higher education.

The LHEIs cannot actually build a respectable collaborative learning or e-learning environment without developments in teaching, research, good networking connections, modern software, and contemporary computer applications development. The highly skilled human resource development is also a foundation of ICT in higher education institutions. The networked learning environment in higher education requires significant government intervention. Government policy has a real impact on strategic initiatives in universities and often determines the parameters of such initiatives through laws, regulations, and the allocation of funds.

At the same time, the LHEIs should play a key role in articulating national e-strategies. Universities could play a monitoring, mentoring, and evaluation role in shaping ICT laws and regulations.

This paper focused on the analysis of ICT impact on the effectiveness of collaborative learning processes in LHEIs. A questionnaire was completed by mature Libyan students, divided into two categories: the first category is a group of researchers in the UK who were also full-time lecturers from different universities in Libya; the second category is full-time lecturers from the same universities. Their answers referred time spent on the internet; time spent using technology in teaching; the value of using intelligent multimedia applications; benefits of e-learning implementation and the barriers that face it. Satisfaction with internet implementation and cost of off-campus access were also considered.
The findings showed that the participants in the UK were aware of the internet and intelligent multimedia value, and they spent more time using the Internet than the participants who worked in Libyan universities; however, participants who worked in Libya spent more time in teaching than those in the UK. Furthermore, there was an agreement between both groups of participants that implementing e-learning in the LHEIs would increase achievement and that it provided a set of benefits. The most important element of the e-learning implementation was the development of ICT. On the other hand, the main barriers that can face both groups were mismanagement and technological challenges. Additionally, the participants who studied in the UK were more satisfied with the Internet speed provided on-campus than those in Libya were. Finally, the cost of the Internet off-campus was problematic for participants who worked in Libyan universities. Likewise, the paper has presented other factors such as intelligent multimedia, internet technologies, knowledge management and how these have a significant influence on creating innovative and inspiring collaborative learning environments, where lecturers are expert designers of intellectual experiences for students who become active participants in the learning processes. In addition, the fundamental role of the lecturers and students in development of the LHEIs was discussed. Finally, the paper concluded that some LHEIs have already shown success in the implementation and management of collaborative learning and Internet technologies and applications; those institutions should be encouraged to share their success with other institutions. There should be cooperation between government teams responsible for the LHEIs. Governmental departments and the private sector should be encouraged to sponsor the development of Internet technologies in HEIs that can produce staff that are competent in such technologies.

\section{References}

[1] Till, G. (2003). Harnessing distance learning and ICT for higher education in Sub- Saharan Africa: An examination of experiences useful for the design of widespread and effective tertiary education in Sub-Saharan Africa. Report to the Rockefeller Foundation.

[2] A. Rhema, W. Miliszewska, "The Potential of E-Learning in Assisting Post-Crisis Countries in Re-Building Their Higher Education Systems: The Case of Libya". Issues in Informing Science and Information Technology, Vol. 9, pp.149-160, 2012. [Accessed 13 Sep. 2013]

[3] T. Kenan, C. Pislaru and A. Elzawi, "Novel SWOT Analysis of E-learning Implementation in HE Institutions in Libya". International journal on E-learning (IJEL): 
Association for the Advancement of Computing in Education (AACE), 2013. (to be published).

[4] M. Artemi and K. Ajit, "A SWOT Analysis of E-Learning Model for the Libyan Educational Institutions." The 3rd National Conference of Basic Science. Aljabal Algharbi; University of Gharian- Libya, 2009.

[5] Lishan A. (2003), 'Information and Communication Technologies in Higher Education in Africa: Initiatives and Challenges'. JHEA/RESA 1, (1), pp.195-221.

[6] M. Porter and D. Yegin, "National economic strategy: an assessment of the competitiveness of the Libyan Arab Jamahiriya". the general planning council of Libya. Cera, UK, 2006.

[7] A. Elzawi, T. Kenan, S. Wade, and C. Pislaru, "Bridging the Digital Divide and Enhancing the Quality of Engineering Research in Libyan Universities". In: 6th Conference on Quality in Middle East, 2012, Hamdan Bin Mohammed University, Dubai, 2012.

[8] A. Rhema and W. Miliszewska, "Towards E-Learning in Higher Education in Libya. Issues in Informing Science and Information Technology", (2010). Vol. 7, pp.423-437. Available at: < Towards E-Learning in Higher Education in Libya > [Accessed 8 Sep. 2013]

[9] T. Kenan, C. Pislaru and A. Elzawi, A. "Analysing the effectiveness of e-learning based on national and international cultures and approaches to pedagogy". In: 17th UKAIS Conference on Information Systems, 2012, New College, Oxford University, 2012.

[10] J. M. Twatti, "The impact of organizational culture innovation on the adoption of IS/IT: the case of Libya", Journal of Enterprise Information Management. Vol. 19, No.2, PP. 175-191, 2006.

[11] A. Elzawi and S. Wade, "Barriers to ICT adoption in quality of engineering research in Libya: how to bridge the digital divide?", in: Proceedings of The Queen's Diamond Jubilee Computing and Engineering Annual Researchers' Conf.; CEARC'12. UK: University of Huddersfield. 2012, pp.98-103, 2012.

[12] Y. Sarayrah, "Resistance to innovation teaching methods in public administration education in Jordan". Miami, USA. Public administration challenges of inequality and exclusion, 2003.

[13] A. Bhatti, A. Tubaisahat, and E. El-Qawasmeh, "Using technology-mediated learning environment to overcome social and cultural limitations in higher education". Issues in Informing Science and Information Technology, (2), pp.67-76, 2005.

[14] A. Othman, C. Pislaru, T. Kenan and A. Impes, “Analysing the Effectiveness of IT Strategy in Libyan Higher Education Institutes." International Journal of Digital Information and Wireless Communications (IJDIWC), 3 (3). pp.114-129. 2013

[15] Keats, D. (2002). 'Collaborative development of open content: A process model to unlock the potential of African universities', Retrieved from: http:/ /www.firstmonday.dk/issues/issue8_2/keats/\#note1(20 May 2013)

[16] J. W. Creswell. Research design: qualitative, quantitative, and mixed methods approaches. Thousand Oaks: Sage Publication, 2009.

[17] Bryman, A. Research methods and organization studies. Contemporary Social Research Series (1st ed.). London, 1989.

[18] Jensen, M. (2012) The Regional Informatics Network for Africa (RINAF): An external evaluation for UNESCO. Retrieved from: http:// www.unesco.org/webworld/build_info/rinaf_ev.rt. (29 Dec.2012)

[19] G. Salmon, "Flying not flapping: a strategic framework for e-learning and pedagogical innovation in higher education institutions". Association for Learning Technology (ALTJ), Research in Learning Technology, (13), No. 3, pp.201-218, October 2005. 